\title{
CSR Disclosure: Effects of Political Ties, Executive Turnover and Shareholder Equity. Evidence from China
}

\author{
Fawad Rauf ${ }^{1,2,3}$, Cosmina L. Voinea ${ }^{1, *(1)}$, Khwaja Naveed ${ }^{1,3}$ (1) and Cosmin Fratostiteanu 4 \\ 1 Faculty of Management, The Open University of the Netherlands, \\ P.O. Box 2960, 6401 DL Heerlen, The Netherlands; fawad.rauf@ou.nl or fawadraufkhan@gmail.com (F.R.); \\ khwaja.naveed@ou.nl (K.N.) \\ 2 Department of Management Sciences, National University of Modern Languages (NUML), \\ Islamabad 44000, Pakistan \\ 3 Department of Commerce and Management Sciences, University of Malakand, Dir Lower 18300, Pakistan \\ 4 Faculty of Economics and Business Administration, University of Craiova, 200396 Craiova, Romania; \\ cosminfratostiteanu@yahoo.com \\ * Correspondence: cosmina.voinea@ou.nl
}

Citation: Rauf, F.; Voinea, C.L.; Naveed, K.; Fratostiteanu, C. CSR Disclosure: Effects of Political Ties, Executive Turnover and Shareholder Equity. Evidence from China. Sustainability 2021, 13, 3623. https://doi.org/10.3390/su13073623

Academic Editor:

Josep Garcia-Blandon

Received: 1 March 2021

Accepted: 18 March 2021

Published: 24 March 2021

Publisher's Note: MDPI stays neutral with regard to jurisdictional claims in published maps and institutional affiliations.

Copyright: (C) 2021 by the authors Licensee MDPI, Basel, Switzerland. This article is an open access article distributed under the terms and conditions of the Creative Commons Attribution (CC BY) license (https:// creativecommons.org/licenses/by/ $4.0 /)$.

\begin{abstract}
The context of China fosters different contextual factors, which influences the quality of corporate social responsibility (CSR) disclosure in comparison to firms across the rest of the world. Political ties at a corporate level are one of these vital factors. This paper studies the influence of firmlevel political ties (PT) and executive turnover (ET) on the quality of CSR disclosure in the context of shareholding status of departing executive in Chinese listed A-share firms. Stakeholder and Agency theories are applied to the dissemination of CSR disclosures in Chinese firms whereby we used 20,578 firm-years interpretations of Chinese registered companies between 2012 and 2019. The results foster a negative link between executive turnover and quality of CSR disclosures. In addition, a negative relationship has been found between political ties and the quality of CSR disclosure. The findings disclose that the shareholding status of departing executive moderate the relationship between the impact of political ties and executive turnover on firms quality of CSR disclosure, whilst the effect of executive turnover on the quality of CSR disclosure was found more pronounced for firms whose departing executive held larger shareholding (SH). This study contributed to the literature on the quality of CSR disclosure while recognizing the negative effect of executive turnover on a firm's quality of CSR disclosure for politically tied firms with a reinforcing moderating role of the shareholding status of departing executive.
\end{abstract}

Keywords: corporate social responsibility (CSR); CSR disclosure quality; Executive turnover; Political ties; Shareholding; Shareholder equity

\section{Introduction}

In China, companies are usually politically connected, and a huge part of the literature shows that political ties hold considerable significance for firms. In theory, the Shleifer and Vishny [1] model of bargaining shows that political parties cater to pressure groups and organized companies, and these groups and companies harness a big proportion of their office's supportive role as compared to the general public, as the public are disorganized [1,2]. Crony capitalism also recommends that political parties' leaders take advantage of their power to make rentals for their relatives and family member trades.

Upper echelon theory is a widely cited theory for the distinguished role of the executive. For instance, in [3-9] executive are deemed the brain of an organization and the most responsible for its concordances and discrepancies. In the same manner, the role of executive in CSR provision has also been found to be significant in some earlier studies [10-12], having an extended connection with executive turnover [13,14]. This phenomenon is concomitant with modern corporate governance [15], having a different scope 
in different countries depending upon the governmental regulations, corporate culture, and human resource pool [16]. The fulfillment of the purpose of the CSR report is hampered by different reasons whereby executive turnover is deemed to be one of the prominent reasons. It has been studied in terms of its causal relationships with different antecedents and impacts, for voluntary and involuntary turnover, including but not limited to large outside shareholders, the poor performance of firms, governmental ownership, and incumbent power. Few pieces of research, nevertheless have examined the negative influence of political ties on CSR [17-19]. Therefore, empirical insight into the relationship between executive turnover and quality of CSR disclosure for political firms is direly needed.

Previous research mentions that the quality of CSR disclosure can influence shareholders' comprehension of the company's performance, risks, and value positively [17,20-28]. Furthermore, the quality of CSR disclosure decreases information irregularity among executive, shareholders, and other stakeholders, and relieves the firm grip and control of executive. Efficient boards are thus predicted to encourage the quality of CSR disclosure $[29,30]$. Furthermore, the quality of CSR disclosure in yearly information provides panels to indicate their stability among economic and social objects [20,31].

Stakeholder theory is the prevalent theory inculcated in the studies related to CSR. Freeman [32] promoted the theory of stakeholders to suggest a new pattern in strategic management. The explanation of stakeholder's concentration on the interconnection among institutions and several of its categories, like Customers, workers, suppliers, shareholders, public, climate, etc. was well received. This theory promulgates that firms should maintain strong interactions with the relevant stakeholders $[33,34]$ and that the quality of CSR disclosure, as an important instrument of this interaction, could deliberate the main stakeholders [35,36]. Snider and Martin [37] Suggested that stakeholder theory is an acceptable structure to assess the quality of CSR disclosure. The extensive increase in financial numbers and improvement in macroeconomic indicators qualified by the Chinese economy in the current years has pushed business growth in a number of shareholding firms. As the world is biggest intermediate financial and developing marketplace, China has realized a sequence of rules concerning the quality of CSR disclosure whereby its quality is of appreciable attention to shareholding controllers and researchers.

The first research question that we ask regards the relationship between executive turnover and the quality of CSR disclosure. We address this by using a complete measure of CSR and by looking at numerous sub-components that contribute to the overall CSR. The second research question is how does a firm's affect the quality of CSR disclosure? The third question regards the role of the shareholding status of departing executive in the connection between and quality of CSR disclosure for a firm?

The contributions of our study are many and multi-folded. First, the literature on the effects of executive turnover on the quality of CSR disclosure in political ties firms is scant and therefore it will enhance our understanding of this phenomenon in the premise of upper echelon and stakeholder theories. Second, the contextual and moderating role of the shareholding status of the departing executive inculcates the agency perspective in a more pronounced manner. The answers to this question are interesting and contribute to our understanding of the interplay between executive turnover and quality of CSR disclosure in the firms in the context of shareholding status, as no previous study has looked at this interplay. This is important for individual researchers and policymakers who are interested in antecedents of quality of CSR disclosure of firms.

The rest of the study is organized as follows: Section 2 presents the literature review and hypotheses development; Section 3 explains the methodology; Section 4 presents the descriptive statistics, correlation matrix; Section 5 results and, finally, Section 6 presents the conclusion and limitations. 


\section{Literature Review and Hypotheses Development}

\subsection{Executive Turnover and Quality of Corporate Social Responsibility Disclosure}

A great deal of research is underway on executive turnover across various disciplines like psychology, economics, sociology, and management. Each discipline has its focus and accordingly employs different research methodologies. For example, psychologists are specifically interested in the motivation behind turnover while economists are more interested in the outcomes relevant to firms' economic performance. In management studies, these issues have been of continuous concern, especially in organizational and strategic management disciplines. Bowen and Siehl [38] recognized the profitability and comfort of movement as important antecedents for turnover while building their proposition based on Willamson [39]. Also, Jackofsky \& Peters [40] has enumerated the tradeoff between the profitability of movement in the sensed job option and feeling of gratification as a push to a decision for turnover or retention [41]. Instead of vehement research on employee turnover in general and executive turnover from an organizational and strategic management perspective, the relationship is rarely being worked on with the quality of CSR disclosure. The departing and incoming executive traits are likely to affect the quality of CSR disclosure due to many reasons. Firstly, an incoming executive from outside of the firm will plausibly apply adjustments and modifications in contrast to an internal replacement whereby the status quo is more plausible to be maintained [42-44]. Secondly, an internal replacement is more likely for a smooth transition of authority and there will be a little possibility of release of a poor report connoted with the departing executive [45,46]. Executive turnover is studied in terms of financial performance and a negative association has been detected between executive turnover and a firm's financial performance. For example, industry-adjusted stock returns are found to be negatively associated with executive turnover $[47,48]$. Executive may leave firms voluntarily or by force. If an executive takes leave till the retirement age or agreement expiration, it can be treated as a normal turnover and it is reported as having no relation with the firm's performances [16]. Also, the executive who receive large bonus payments or lucrative board seats after retirement are treated as voluntary turnover $[49,50]$. In contrast to that, if executive are forced to leave a firm for reasons other than that of age, tenure, or health issues, it is regarded as involuntary turnover. Involuntary turnover has been worked on for its causes and outcomes in terms of organizational adaptation theory, agency theory, and relational theory (social psychological perspective) whereby executive are considered influential at par in a firm's decision-making and its performance and therefore we constitute the first hypothesis of the study as follows.

Hypothesis (H1): Firms with executive turnover will issue corporate social responsibility disclosure more slowly and less substantively (i.e., more symbolic or with lower quality) as compared to the firms without an executive turnover.

\subsection{Political Ties and Quality of Corporate Social Responsibility Disclosure}

The firms having strong governmental ties are known as politically ties firms. These ties might be through network connections or state ownership [51,52]. One form of this phenomenon is to have government officials in the service of an organization's executive or directors, literally embedding political affiliates in economic organizations [53,54]. This phenomenon is on the horns of a dilemma as on one hand, it may leverage the firms with ingress to government's valuable resources but on the other hand, it makes them liable for extra limelight of government monitoring. It decreases the uncertainty for firms while extending to them the knowledge about the pragmatics of accomplishments of tasks in state agencies in the form of navigating state agencies, clarifying regulatory processes, and improving understanding of state functionaries. It instills a kind of informality in business state relationships by envisaging the base of state-business relations on shared goals [55] resulting in trust building between state and business. This trust and knowledge may lead to the exchange of favors with bureaucrats and incline them to lightening the 
regulatory load on firms, relaxation in tax and other fees, and easing in the provision of resources controlled by the state in the form of loans and land use rights [56,57]. Therefore, the political ties of a firm can support them to reduce the uncertainty of survival while extending companies with enormous assistance. On the other side, however, the political ties of firms inflict an extra burden on the company's financial performance. It can affect the whole intricacy of interior corporate governance [58]. For instance, Fan and Zhang [59] find that politically embedded firms' boards are inhabited by other government officials with less expertise and experience. This is prone to bad quality of parameters of corporate governance in these firms and harms turnover performance.

Chinese market structure provides a very good example of politically ties firms [51]. Albeit the emergence of a decentralized market-oriented system, there is still strong governmental control [60]. Amid devolution plans of companies, several companies have been updated from government-controlled entities into public traded companies, nevertheless, a majority of shareholding still lies in the hands of the government. Consequently, the ownership and actual control of firms lie in the hands of the government at par [61,62]. Moreover, often the executive of firms also happen to be public office bearers, which depict political connections between firms' senior executive and government $[51,63,64]$. In the big picture, China represents a well-suited and classical empirical setting for the analysis of political ties firms.

On the governmental level in China, there has been a shift of acknowledgment of the environmental and social effects of corporate activities and has therefore signaled CSR reporting as an important and desired activity. For instance, the Communist Party Committee put forward a statement to ensure the benchmarks of social responsibility between individual, national, corporate firms, and all types of companies [63,64]. Consequently, financial institutions like the Shenzhen and Shanghai stock exchanges worked out guidelines and standards for the quality of CSR disclosure $[65,66]$. Apart from that, the Chinese government has also directed businesses with its mandatory reporting standards for the disclosures of Chinese firms [51,67]. It is observed that in general, the Chinese government can be regarded as a principal driver and promoter of CSR activities [60].

In terms of CSR engagement and its quality, the foremost area of focus for researchers in this regard is the issuance of a CSR report in the first place. Legitimacy theory which questions the justification of the existence of firms and associates it with society's prerogative rather than an inherent right is a basic premise considered by early researchers in this regard $[68,69]$. Thus, this is required for firms to access necessary resources for the successful conduct of business require political legitimacy. This is the perceived compliance level of a firm to the governmental laws and norms [51]. Therefore, that if a government conditions quality of CSR disclosure as a desired activity, political legitimacy is on the disposal of issuance of CSR report. In tandem with this background, it can be claimed that politically ties firms have already an advantage of political legitimacy and are therefore disincentivized for the compliance of quality of CSR disclosure per se. Notwithstanding, a control-oriented perspective contradicts the above proposition in the sense that it promotes the view of the behavior of firms to be dependent upon regulatory pressure from the government $[70,71]$. In the case of China, this view is of importance in the sense that firms with political ties are considered to be the nurturers of governmental policies [72]. To maintain their repute and legitimacy in the eyes of the government and securing a future political career, the executive with political connections abide by the government policies per se [51,73]. Agency theory, however, promulgates that the activities of issuance of CSR reports will be underpinned by self-interest and self-promotion and are prone to compromising the interests of owners and other stakeholders. In light of the above discussion, we propose that the quality of CSR disclosure will be compromised in this whole scenario and formulate the following hypothesis.

Hypothesis (H2): Firms with political ties will issue corporate social responsibility disclosure more slowly and less substantively than those firms, which have no political ties. 


\subsection{Moderating Role of Shareholding}

In the previous sections, we have discussed that executive turnover and political ties of firms will have a negative association with firms' quality of CSR disclosure. This relation can be influenced by the shareholding status of the departing executive. Firm ownership is a growingly influential factor for corporate governance and the quality of CSR disclosure attributes [74]. When ownership is distributed enough, its role is marginal in the monitoring and evaluation of the firm's performance owing to its cost-benefit ratio. The managerial agency problem hence arises, as the principals are less motivated and less resourceful to do so. This dilemma leaves the market forces as the controllers for the managerial check $[75,76]$. Notwithstanding, when ownership of a firm is less dispersed and more concentrated, the role of large shareholders becomes important in monitoring and evaluation $[77,78]$ leading to the pyramiding and tunneling effect of ownership. Chen and Xia [79] established that the ownership concentration of shareholders affects the level and quality of CSR disclosure. In the Chinese context, there are two types of ownership by and large, i.e., state ownership and non-state ownership. The case of non-state ownership is relevant here.

The incentives of large shareholders to use their controlling position are prone to extracting personal benefit to the detriment of minority shareholding which results in agency problems [80,81]. Large shareholders may be more incentivized to overinvest in CSR activities and report them. The government's benchmarked CSR activities will be carried out overwhelmingly to serve for good image and reputation of CSR-friendly shareholding [82]. Now the quality of CSR depends on the willingness and motivation of the executive as discussed earlier, which is directly influenced by his/her stakes and control. If the executive departs from the controlling position, his/her motivation and control will no longer remain and will lead to harm to the willingness and motivation for quality of CSR disclosure on part of the executive. Thus, we state the following hypotheses:

Hypothesis (H3): The effect of executive turnover on firms and quality of corporate social responsibility disclosure will be stronger for companies whose departing executive hold larger shareholding.

\section{Methodology}

\subsection{Sample and Data}

Our study sample includes all public A-share companies of China, which are registered on the Shenzhen Stock and Shanghai Exchanges for the period 2012-2019. They are summarized using the comparative study of the annual survey of the listed company. Separate CSR reports are extracted from the Chinese Stock Market and Accounting Research database (CSMAR). This database collects information from the annual reports and financial reports of Chinese listed firms. As the study requires personal information of the departing executive for the previous years to measure their political ties, therefore the span of the study has been extended to seven years. The firms with non-availability of data for a specific variable were omitted and hence the final sample comprised of a total of 20,578 firm-years observations.

\subsection{Empirical Model and Measures}

To test the quality of CSR disclosure relationship with executive turnover, political ties of firms, and shareholding status of departing executive, this study utilizes the ordinary least squares (OLS) regression model. This model can be specified as follows:

$$
\begin{aligned}
& \operatorname{CSRD}_{(i, t)}=a+\beta_{1} E T+\sum_{i=1}^{N} \beta_{n} \operatorname{controls}_{(i, t)}+\varepsilon_{(i, t)} \\
& \operatorname{CSRD}_{(i, t)}=a+\beta_{2} P T+\sum_{i=1}^{N} \beta_{n} \operatorname{controls}_{(i, t)}+\varepsilon_{(i, t)}
\end{aligned}
$$




$$
\begin{gathered}
\operatorname{CSRD}_{(i, t)}=a+\beta_{3} E T+\beta_{4} P T+\beta_{5} S H+\sum_{i=1}^{N} \beta_{n} \text { controls }_{(i, t)}+\varepsilon_{(i, t)} \\
\operatorname{CSRD}_{(i, t)}=a+\beta_{5} E T+\beta_{6} E T \times S H+\sum_{i=1}^{N} \beta_{n} \operatorname{controls}_{(i, t)}+\varepsilon_{(i, t)} \\
\operatorname{CSRD}_{(i, t)}=a+\beta_{7} P T+\beta_{8} P T \times S H+\sum_{i=1}^{N} \beta_{n} \text { controls }_{(i, t)}+\varepsilon_{(i, t)}
\end{gathered}
$$

In the above statistical model, CSRD indicates the quality of CSR disclosure, ET indicates executive turnover, PT denotes political ties, $\mathrm{SH}$ indicates shareholding. $\mathrm{PT} \times \mathrm{SH}$ indicates moderating role of political ties and shareholding. ET $\times \mathrm{SH}$ shows the moderating role of executive turnover and shareholding. Controls refer to other variables considered

\begin{tabular}{|c|c|c|}
\hline Variables & Abbreviation & Description \\
\hline $\begin{array}{l}\text { Corporate Social } \\
\text { Responsibility Disclosure }\end{array}$ & CSRD & $\begin{array}{l}\text { CSR disclosure is a report regarding } 11 \text { non-financial parameters for performance } \\
\text { appraisal. It is a dummy variable. Its value will be } 1 \text { if a (CSRD) is carried out in a } \\
\text { particular year and } 0 \text { otherwise. }\end{array}$ \\
\hline Political Ties & PT & $\begin{array}{l}\text { It is also a dummy variable concerning the political ties }(\mathrm{PT}) \text { of executive. Its value } \\
\text { is equal to } 1 \text { if the executive are political ties and } 0 \text { if not connected. }\end{array}$ \\
\hline Executive Turnover & ET & $\begin{array}{l}\text { It is also a dummy variable concerning the timing of executive turnover (ET). Its } \\
\text { value is equal to } 1 \text { if the executive turnover occurs in the ongoing year and } 0 \\
\text { otherwise }\end{array}$ \\
\hline Shareholding & $\mathrm{SH}$ & $\begin{array}{l}\text { It is the status of shareholding }(\mathrm{SH}) \text { of the departing executive as to whether } \\
\text { he/she is a large shareholder or a minor one. }\end{array}$ \\
\hline Board Size & BS & It is a variable concerning the size of the board of directors. \\
\hline Independent Director & ID & $\begin{array}{l}\text { It is a variable showing if the minimum number of independent directors i.e., } 2 \text { are } \\
\text { present on BOD. This variable is assigned with the value } 1 \text { if it is so and } 0 \\
\text { otherwise. }\end{array}$ \\
\hline Tobin's Q & TQ & $\begin{array}{c}\text { It is a variable concerning the percentage between the market value and the added } \\
\text { value of a physical asset. }\end{array}$ \\
\hline Book to Market Ratio & BTMA & It is a variable concerning the book to market ratio of shareholders' equities. \\
\hline Asset Growth & AG & This variable is the measure of the increase or decrease in total assets. \\
\hline Return on Assets & $\mathrm{ROA}$ & It is a variable concerning the ratio of total profit over a total asset. \\
\hline Return on equity & ROE & It is a variable concerning the ratio of profit to the proportion of equity. \\
\hline Board Meeting & BM & It refers to the number of management reviews/meetings held per year. \\
\hline Financial Leverage & FL & It is the ratio of the total debt of a firm to its total assets. \\
\hline Number of Employees & NE & It is the percentage of workers as union members in the firm's industry \\
\hline Year and industry & YI & $\begin{array}{l}\text { The industry dummies are included in all regressions in order to control for the } \\
\text { effects of year and specific industry. }\end{array}$ \\
\hline
\end{tabular}
in this study to estimate their effect. For descriptions, see Table 1.

Table 1. Variable's Description.

\subsection{Measuring the Quality of CSR Disclosure}

For the measurement of the quality of CSR disclosure, a disclosure index is formulated to rate the firms based on CSR disclosures. The source of data is the CSMAR database. This task is traditionally performed as per the Global Reporting Initiative's (GRI) Sustainability Reporting Guidelines $[65,73,83]$. The contextual regulations' differences affect the process as they vary among republics [84,85]. In the context of China, we have developed the gauges based on the ten items already prescribed for the non-financial information by regulators in China. The items are enumerated as follows: Protection of shareholders in 
terms of corporate governance, meeting the benchmarks of returns, risk control, regularity in disclosure of operational information, shareholders review meetings, and timely communication.

i. Creditor protection in terms of responsibility for debts amount and the provision of information to the banks and its debtors.

ii. Protection of staff in terms of minimum wages, health and safety, equal promotional opportunities, well-being guarantees, and staff training.

iii. Delivery protection in terms of abiding by the principles of commitments, fair and just procurement, legitimate contracts in compliance with the law, ensuring industrial development, and sharing experiences.

iv. Protection of customers in terms of the provision of quality management services and the production of high-quality products.

v. Environmental protection in terms of role in climate change, reduction in energy consumption and greenhouse gases, and protection of the ecosystem.

vi. Public relations in terms of promotion of social development and care of vulnerable and unprivileged people.

vii. System construction in terms of formulation of procedures and routines to systemize the CSR.

viii. Work safety in terms of workplace and production safety.

ix. Deficiency in terms of shortcomings in the implementation of the CSR measures in the shape of lack of training, worker safety, communication with shareholders, etc. in the firm.

x. Reporting Deficiencies of Company.

These items were assigned with scores ranging from 0 to 3 points. The score will be 0 if there is no information existing, 1 if only non-quantitative aggregate information is available, 2 if quantitative information is provided, and 3 if fiscal information is available $[86,87]$. The quality of CSR disclosure is defined with an iterating value of $(i)$ for each firm and $(t)$ for the year concerned whereby each sampled firm is assigned a score of quality of CSR disclosure in the 20,578 firm-year observations as shown in Equation (1).

$$
\operatorname{CSRD}_{(i, t)}=\Sigma_{j=1}^{11} \operatorname{Score}\left(I_{i, t}^{j}\right)
$$

So the quality of $C S R D_{i, t}$ represents the aggregate rating for all items included in the CSR report of the firm's at year $(t)$. On the other side, Score $\left(I_{i, t}^{j}\right)$ represents the rating of the item number $(j)$ for firm number $(i)$ at a specific year $(t)$. The value of $j$ is from 1 to 11 .

\subsection{Measuring Executive Turnover and Political Ties}

Two independent variables are used in this study. One of these is executive turnover (ET) and the other is political ties (PT). Executive turnover is a dummy variable concerning the turnover of the executive. Its value is equal to 1 if the executive turnover occurs in the ongoing year and 0 otherwise. In concordance with prior studies [88-90], Political ties are also taken as a dummy variable, which proceeds the value 0 if the firm does not politically tie and 1 otherwise. The political ties of the firm are determined through the connection of at least one of the executive, directors, or supervisors with the government, National People's Congress (NPC), and/or Chinese people's political consultative conference (CPPCC) [63,91,92].

\subsection{Measuring Moderating Role of Shareholding}

It is the status of shareholding ( $\mathrm{SH}$ ) of the departing executive as to whether he/she is a large shareholder or a minor one [91,92]. Shareholding is a dummy variable that equals one if the firm's executive has large shareholding $(10 \%$ or more of the shareholding in the year), and 0 otherwise [93]. 


\subsection{Control Variables}

To control for potential variables which might influence the quality of CSR disclosure, a variety of control variables are used in this study [71,94]. Board size is regarding the number of directors on the board of directors. The minimum number of independent directors has been included as a control variable. Tobin's $Q$ is also a control variable depicting the percentage between the market value and the added value of a physical asset. BTMA is another control variable showing the book to market ratio of shareholders' equities. Asset growth is yet another control variable depicting the increase or decrease in the total assets of the firm. ROA is also a control variable representing a return on the asset while ROE represents a return on equity. The number of management review or board meetings has also been included as the control variable. Financial leverage represents the ratio of the total debt of a firm to its total assets. A dummy variable for industry and another for the year was also included to control for the possible effects of time and specific firms $[95,96]$.

\section{Descriptive Statistics}

The descriptive statistics of the sample firms' reports are tabulated in Table 2. Out of the 20,578 firm-year observations in the full sample, 3256 firms (24\%) issued CSR reports in the given year. Among these 3442 firms, 16\% ensured CSR reports quality, and 60\% published CSR reports under CSR Information. The mean quality of CSR disclosure is 5.807 while having a standard deviation of 2.479. It represents the achievement of 5.807 percent of the benchmarked composite CSR information in the context of China. The maximum possible rating is 8 .

Table 2. Descriptive statistics.

\begin{tabular}{ccccc}
\hline Variables & Mean & SD & Min & Max \\
\hline CSRD & 5.807 & 2.479 & 0.001 & 8.000 \\
\hline ET & 0.273 & 0.445 & 0.000 & 1.000 \\
\hline PT & 0.105 & 0.306 & 0.000 & 1.000 \\
\hline SH & 19.00 & 5.439 & 0.000 & 26.600 \\
\hline BS & 9.483 & 2.282 & 4.000 & 22.000 \\
\hline ID & 3.493 & 0.839 & 1.000 & 8.000 \\
\hline TQ & 1.752 & 1.813 & 0.096 & 33.27 \\
\hline BTMA & 1.186 & 1.153 & 0.030 & 10.32 \\
\hline AG & 0.166 & 0.343 & -0.828 & 10.88 \\
\hline ROA & 0.042 & 0.057 & -0.690 & 0.481 \\
\hline ROE & 0.082 & 0.816 & -18.561 & 43.610 \\
\hline BM & 10.21 & 4.791 & 1.000 & 57.000 \\
\hline FL & 0.509 & 0.214 & 0.007 & 1.344 \\
\hline NE & 7.527 & 1.422 & 1.098 & 13.222 \\
\hline
\end{tabular}

\section{Correlation Matrix}

Table 3 reports the correlation matrix. The correlation between the quality of CSR disclosure and executive turnover is negatively significant with a value of -0.305 . The correlation between political ties and the quality of CSR disclosure is also negatively significant with a value of -0.078 . There is a positive relationship between shareholding and the quality of CSR disclosure. The above results are in line with the prior studies and the correlations are within the operational limits. 
Table 3. Correlation Matrix.

\begin{tabular}{|c|c|c|c|c|c|c|c|c|c|c|c|c|c|c|}
\hline Variables & (1) & (2) & (3) & (4) & (5) & (6) & (7) & (8) & (9) & (10) & (11) & (12) & (13) & (14) \\
\hline CSRD & 1.0000 & & & & & & & & & & & & & \\
\hline ET & $-0.305^{*}$ & 1.0000 & & & & & & & & & & & & \\
\hline $\mathrm{SH}$ & 0.340 * & $-0.445^{*}$ & -0.013 * & 1.0000 & & & & & & & & & & \\
\hline BS & $-0.040 *$ & $0.050 *$ & $-0.036^{*}$ & $0.039 *$ & 1.0000 & & & & & & & & & \\
\hline ID & -0.031 * & 0.030 * & -0.010 * & 0.054 * & 0.585 * & 1.0000 & & & & & & & & \\
\hline TQ & 0.024 * & $-0.058^{*}$ & $0.080 *$ & $0.011 *$ & $-0.164^{*}$ & $-0.157^{*}$ & 1.0000 & & & & & & & \\
\hline BTMA & -0.024 * & $0.014^{*}$ & $-0.075^{*}$ & $0.093 *$ & 0.097 * & $0.155^{*}$ & $-0.510 *$ & 1.0000 & & & & & & \\
\hline AG & -0.054 * & -0.001 & $0.046^{*}$ & $0.005 *$ & $-0.027 *$ & $-0.019 *$ & 0.109 * & $-0.055^{*}$ & 1.0000 & & & & & \\
\hline ROA & $-0.025 *$ & $-0.005^{*}$ & $0.068^{*}$ & $0.039 *$ & -0.002 & $-0.016^{*}$ & $0.333 *$ & $-0.294^{*}$ & $0.165 *$ & 1.0000 & & & & \\
\hline ROE & -0.053 * & 0.019 * & $0.037^{*}$ & $0.009 *$ & $0.013 *$ & 0.013 * & $0.105^{*}$ & -0.091 * & $0.103 *$ & 0.563 * & 1.0000 & & & \\
\hline $\mathrm{BM}$ & $-0.066^{*}$ & $0.018^{*}$ & $0.009 *$ & $0.061 *$ & $0.005 *$ & $0.045^{*}$ & -0.099 * & $0.163 *$ & $0.103 *$ & $-0.106^{*}$ & -0.013 * & 1.0000 & & \\
\hline FL & -0.018 * & 0.028 * & -0.064 * & 0.020 * & $0.116^{*}$ & $0.147^{*}$ & $-0.504^{*}$ & $0.513^{*}$ & $-0.035^{*}$ & $-0.417^{*}$ & $-0.103^{*}$ & $0.222 *$ & 1.0000 & \\
\hline $\mathrm{NE}$ & -0.035 * & $-0.035^{*}$ & $-0.018^{*}$ & 0.157 * & 0.234 * & $0.296^{*}$ & $-0.308^{*}$ & $0.348^{*}$ & -0.043 * & $-0.008^{*}$ & $0.028 *$ & 0.060 * & 0.293 * & 1.0000 \\
\hline
\end{tabular}




\section{Results and Analysis}

Table 4 reports OLS regression results for the effects of and on the quality of CSR disclosure. Model 1 presents the relationship between the quality of CSR disclosure and while testing hypothesis 1 . Model 2 presents the relationship between the quality of CSR disclosure and political ties while testing hypothesis 2 . Model 3 shows a moderation of executive turnover and dependent quality of CSR disclosure with shareholding status while testing hypothesis 3. In Models 4 and 5, the interaction of quality of CSR disclosure is observed on political ties and executive turnover. Hypothesis (H1) shown in the results of Model 1, executive turnover is connected significantly negatively with the quality of CSR disclosure $(\mathrm{t}=-18.44, p<0.000)$, consistent with [97]. Hypothesis $(\mathrm{H} 2)$ results of model 2 show that political ties are also connected significantly negatively with the quality of CSR disclosure $(t=-4.22, p<0.000)$, consistent with $\mathrm{H} 2[71,98]$. Hypothesis $(\mathrm{H} 3)$ the results of model 3 demonstrate a positive linkage of shareholding with executive turnover influence on the quality of CSR disclosure $(t=21.03, p<0.000)$ consistent with H3 [99,100]. Hypothesis (H1) in the model (4), the interaction is observed between the quality of CSR disclosure and executive turnover whereby the coefficient of the interaction term resulted in being significantly negative $(t=-22.03, p<0.000)$, depicting that ensuring quality of CSR disclosure decrease the effect of executive turnover, which supports H1 [71,101]. Hypothesis (H2) in the model (5), the interaction is observed between the quality of CSR disclosure and political ties whereby the coefficient of the interaction term resulted to be significantly negative $(t=-6.36, p<0.000)$ which shows that ensuring the quality of CSR disclosure decreases the impact of political ties [71,102,103]. Table 4 further shows results regarding control variables. Most control variables had an insignificant relationship with the quality of CSR disclosure. The result of the control variables is also consistent with the previous [71,104-107].

Table 4. Results of all models executed through OLS regression.

\begin{tabular}{|c|c|c|c|c|c|}
\hline Variables & Model 1 & Model 2 & Model 3 & Model 4 & Model 5 \\
\hline CSRD & OLS & OLS & OLS & OLS & OLS \\
\hline ET & $\begin{array}{c}-1.533^{* * *} \\
(-18.44)\end{array}$ & & $\begin{array}{c}-0.908^{* * *} \\
(-10.11)\end{array}$ & $\begin{array}{l}-2.088^{* * *} \\
(-22.03)\end{array}$ & \\
\hline PT & & $\begin{array}{c}-0.621 * * * \\
(-4.22)\end{array}$ & $\begin{array}{c}-0.589 * * * \\
(-4.36)\end{array}$ & & $\begin{array}{c}-1.191 * * * \\
(-6.36)\end{array}$ \\
\hline $\mathrm{SH}$ & & & $\begin{array}{c}0.294^{* * *} \\
(15.37)\end{array}$ & $\begin{array}{c}0.262 * * * \\
(14.34)\end{array}$ & $\begin{array}{c}0.231^{* * * *} \\
(13.14)\end{array}$ \\
\hline Interaction & & & & $\begin{array}{c}0.054^{* * *} \\
(11.47)\end{array}$ & $\begin{array}{c}0.051^{* * * *} \\
(4.90)\end{array}$ \\
\hline BS & $\begin{array}{l}-0.017 \\
(-0.53) \\
\end{array}$ & $\begin{array}{l}-0.047 \\
(-1.35) \\
\end{array}$ & $\begin{array}{l}-0.036 \\
(-1.14) \\
\end{array}$ & $\begin{array}{l}-0.014 \\
(-0.46)\end{array}$ & $\begin{array}{l}-0.052 \\
(-1.52) \\
\end{array}$ \\
\hline ID & $\begin{array}{c}0.046 \\
(-0.52)\end{array}$ & $\begin{array}{l}0.073 \\
(0.78)\end{array}$ & $\begin{array}{l}0.061 \\
(0.70)\end{array}$ & $\begin{array}{l}0.043 \\
(0.49)\end{array}$ & $\begin{array}{l}0.083 \\
(0.88)\end{array}$ \\
\hline TQ & $\begin{array}{l}-0.015 \\
(-0.49)\end{array}$ & $\begin{array}{l}0.016 \\
(0.53)\end{array}$ & $\begin{array}{l}-0.023 \\
(-0.78)\end{array}$ & $\begin{array}{l}0.001 \\
(0.05)\end{array}$ & $\begin{array}{l}0.014 \\
(0.46)\end{array}$ \\
\hline BTMA & $\begin{array}{l}-0.002 \\
(-0.04)\end{array}$ & $\begin{array}{l}-0.004 \\
(-0.08)\end{array}$ & $\begin{array}{c}-0.095^{* *} \\
(-2.01)\end{array}$ & $\begin{array}{l}0.001 \\
(0.03)\end{array}$ & $\begin{array}{l}-0.004 \\
(-0.09)\end{array}$ \\
\hline AG & $\begin{array}{c}0.294 \\
(-2.32)\end{array}$ & $\begin{array}{c}-0.293^{* *} \\
(-2.20)\end{array}$ & $\begin{array}{c}-0.281^{* *} \\
(-2.30)\end{array}$ & $\begin{array}{l}-0.124 \\
(-0.99)\end{array}$ & $\begin{array}{c}-0.252^{* *} \\
(-1.90)\end{array}$ \\
\hline ROA & $\begin{array}{l}1.241 \\
(1.21)\end{array}$ & $\begin{array}{l}1.196 \\
(1.11)\end{array}$ & $\begin{array}{l}0.599 \\
(0.61)\end{array}$ & $\begin{array}{l}-0.188 \\
(-0.19)\end{array}$ & $\begin{array}{l}0.994 \\
(0.93)\end{array}$ \\
\hline ROE & $\begin{array}{c}-0.484^{* *} \\
(-2.05)\end{array}$ & $\begin{array}{l}-0.57^{* *} \\
(-2.31)\end{array}$ & $\begin{array}{c}-0.451^{* *} \\
(-1.98)\end{array}$ & $\begin{array}{c}-0.445^{* *} \\
(-1.92)\end{array}$ & $\begin{array}{c}-0.563^{* *} \\
(-2.29)\end{array}$ \\
\hline $\mathrm{BM}$ & $\begin{array}{c}-0.036^{* * *} \\
(-4.09)\end{array}$ & $\begin{array}{c}-0.035^{* * *} \\
(-3.84)\end{array}$ & $\begin{array}{c}-0.042 * * * \\
(-4.99)\end{array}$ & $\begin{array}{c}-0.029 * * * \\
(-3.35)\end{array}$ & $\begin{array}{c}-0.033^{* * *} \\
(-3.59)\end{array}$ \\
\hline FL & $\begin{array}{l}0.309 \\
(1.04)\end{array}$ & $\begin{array}{l}0.208 \\
(0.67)\end{array}$ & $\begin{array}{l}0.505^{*} \\
(1.75)\end{array}$ & $\begin{array}{l}0.322 \\
(1.10)\end{array}$ & $\begin{array}{l}0.189 \\
(0.61)\end{array}$ \\
\hline
\end{tabular}


Table 4. Cont.

\begin{tabular}{cccccc}
\hline Variables & Model 1 & Model 2 & Model 3 & Model 4 & Model 5 \\
\hline CSRD & OLS & OLS & OLS & OLS & OLS \\
\hline \multirow{2}{*}{ NE } & $-0.096^{* * *}$ & $-0.062^{* *}$ & $-0.155^{* * *}$ & $-0.090^{* * *}$ & $-0.060^{* *}$ \\
& $(-2.88)$ & $(-1.78)$ & $(-4.77)$ & $(-2.74)$ & $(-1.74)$ \\
\hline \multirow{2}{*}{ Constant } & $6.655^{* * *}$ & $5.918^{* * *}$ & $-2.016^{* * *}$ & $6.496^{* * *}$ & $5.844^{* * *}$ \\
& $(16.24)$ & $(13.83)$ & $(-3.76)$ & $(16.15)$ & $(13.80)$ \\
\hline YD & Incorporated & incorporated & incorporated & incorporated & incorporated \\
\hline R2 & 0.1209 & 0.0351 & 0.1855 & 0.1549 & 0.0442
\end{tabular}

Notes: ${ }^{*}, * *, * * *$, significant at $10 \%, 5 \%$, and $1 \%$, respectively. T-statistics are reported in parentheses. For a detailed description of the variable, see Table 1.

\subsection{Robustness Test}

To ensure the robustness of our results, we conducted an additional test to verify the main results. The robustness test was carried for additional confirmation of our earlier findings. The findings of our tests are shown in Table 5. This influence of executive turnover, political ties, and shareholding on various categories of quality of CSR disclosure has been examined in these analyses. Table 5 shows that the findings of this analysis are robust to alternative measures.

Table 5. Additional endogeneity and robustness tests.

\begin{tabular}{|c|c|c|c|c|c|}
\hline Variables & Model 1 & Model 2 & Model 3 & Model 4 & Model 5 \\
\hline CSRD & OLS & OLS & OLS & OLS & OLS \\
\hline ET & $\begin{array}{c}-1.533 \text { *** } \\
(-18.57)\end{array}$ & & $\begin{array}{c}-0.908^{* * *} \\
(-9.99)\end{array}$ & $\begin{array}{c}-2.088^{* * *} \\
(-20.80)\end{array}$ & \\
\hline PT & & $\begin{array}{c}-0.621^{* * *} \\
(-4.24)\end{array}$ & $\begin{array}{c}-0.589 * * * \\
(-4.55)\end{array}$ & & $\begin{array}{c}-1.1911^{* * *} \\
(-6.55)\end{array}$ \\
\hline $\mathrm{SH}$ & & & $\begin{array}{c}0.294^{* * *} \\
(17.15)\end{array}$ & $\begin{array}{c}0.234^{* * *} \\
(14.12)\end{array}$ & $\begin{array}{c}0.254^{* * *} \\
(12.12)\end{array}$ \\
\hline Interaction & & & & $\begin{array}{c}0.054 * * * \\
(10.72)\end{array}$ & $\begin{array}{c}0.051 * * * \\
(5.51)\end{array}$ \\
\hline BS & $\begin{array}{l}-0.017 \\
(-0.50)\end{array}$ & $\begin{array}{l}-0.047 \\
(-1.28)\end{array}$ & $\begin{array}{l}-0.036 \\
(-1.06)\end{array}$ & $\begin{array}{l}-0.014 \\
(-0.43)\end{array}$ & $\begin{array}{l}-0.052 \\
(-1.43)\end{array}$ \\
\hline ID & $\begin{array}{c}0.046 \\
(-0.51) \\
\end{array}$ & $\begin{array}{l}0.073 \\
(0.77)\end{array}$ & $\begin{array}{l}0.0611 \\
(0.69)\end{array}$ & $\begin{array}{l}0.043 \\
(0.48)\end{array}$ & $\begin{array}{l}0.083 \\
(0.87)\end{array}$ \\
\hline TQ & $\begin{array}{l}-0.015 \\
(-0.61) \\
\end{array}$ & $\begin{array}{l}0.016 \\
(0.66) \\
\end{array}$ & $\begin{array}{l}-0.023 \\
(-0.94) \\
\end{array}$ & $\begin{array}{l}0.001 \\
(0.07) \\
\end{array}$ & $\begin{array}{l}0.014 \\
(0.58) \\
\end{array}$ \\
\hline BTMA & $\begin{array}{l}-0.002 \\
(-0.04)\end{array}$ & $\begin{array}{l}-0.004 \\
(-0.08)\end{array}$ & $\begin{array}{c}-0.095^{* *} \\
(-1.90)\end{array}$ & $\begin{array}{l}0.001 \\
(0.03)\end{array}$ & $\begin{array}{l}-0.004 \\
(-0.09)\end{array}$ \\
\hline AG & $\begin{array}{l}-0.294 \\
(-1.73)\end{array}$ & $\begin{array}{c}-0.293 \text { ** } \\
(-1.56)\end{array}$ & $\begin{array}{c}-0.281 \text { ** } \\
(-1.82)\end{array}$ & $\begin{array}{l}-0.124 \\
(-1.05)\end{array}$ & $\begin{array}{l}-0.252 \\
(-1.43)\end{array}$ \\
\hline ROA & $\begin{array}{l}1.241 \\
(1.38)\end{array}$ & $\begin{array}{l}1.196 \\
(1.20)\end{array}$ & $\begin{array}{l}0.599 \\
(0.67)\end{array}$ & $\begin{array}{l}-0.188 \\
(-0.21)\end{array}$ & $\begin{array}{l}0.994 \\
(1.00)\end{array}$ \\
\hline $\mathrm{ROE}$ & $\begin{array}{c}-0.484 \text { ** } \\
(-2.66)\end{array}$ & $\begin{array}{l}-0.57 \text { ** } \\
(-2.59)\end{array}$ & $\begin{array}{c}-0.451 \text { ** } \\
(-2.47)\end{array}$ & $\begin{array}{c}-0.445^{* *} \\
(-2.51)\end{array}$ & $\begin{array}{l}-0.563 * \\
(-2.54)\end{array}$ \\
\hline $\mathrm{BM}$ & $\begin{array}{c}-0.036^{* * *} \\
(-3.79)\end{array}$ & $\begin{array}{c}-0.035^{* * *} \\
(-3.62)\end{array}$ & $\begin{array}{c}-0.042 * * * \\
(-4.69)\end{array}$ & $\begin{array}{c}-0.029 * * * \\
(-3.07)\end{array}$ & $\begin{array}{c}-0.033^{* * *} \\
(-3.37)\end{array}$ \\
\hline FL & $\begin{array}{l}0.309 \\
(1.08) \\
\end{array}$ & $\begin{array}{l}0.208 \\
(0.69) \\
\end{array}$ & $\begin{array}{l}0.505^{*} \\
(1.80)\end{array}$ & $\begin{array}{l}0.322 \\
(1.15) \\
\end{array}$ & $\begin{array}{l}0.189 \\
(0.63) \\
\end{array}$ \\
\hline $\mathrm{NE}$ & $\begin{array}{c}-0.096 \text { *** } \\
(-2.81)\end{array}$ & $\begin{array}{c}-0.062 * * \\
(-1.76)\end{array}$ & $\begin{array}{c}-0.155^{* * *} \\
(-4.71)\end{array}$ & $\begin{array}{c}-0.090^{* * *} \\
(-2.66)\end{array}$ & $\begin{array}{c}-0.060 \text { ** } \\
(-1.72)\end{array}$ \\
\hline
\end{tabular}


Table 5. Cont.

\begin{tabular}{cccccc}
\hline Variables & Model 1 & Model 2 & Model 3 & Model 4 & Model 5 \\
\hline CSRD & OLS & OLS & OLS & OLS & OLS \\
\hline \multirow{2}{*}{ Constant } & $6.655^{* * *}$ & $5.918^{* * *}$ & $-2.016^{* * *}$ & $6.496^{* * *}$ & $5.884^{* * *}$ \\
& $(16.86)$ & $(13.62)$ & $(-3.89)$ & $(16.63)$ & $(13.80)$ \\
\hline YI & Incorporated & Incorporated & Incorporated & Incorporated & Incorporated \\
\hline R2 & 0.1289 & 0.0347 & 0.1875 & 0.1548 & 0.0445 \\
\hline
\end{tabular}

Notes: ${ }^{* * *}, * * *$, significant at $10 \%, 5 \%$, and $1 \%$, respectively. T-statistics are reported in parentheses. For a detailed description of the variable, see Table 1.

\subsection{Endogeneity Control}

Apart from our main OLS analyses, we used two different models to discuss the endogeneity problem. Firstly, we used a 1 year lagged value of executive turnover, political ties, and shareholding in models 1,2,3,4, and 5. It was done so under the observation that the performance of a firm needs time before affecting the quality of CSR disclosure. The results of all the models shown in Table 5 foster the findings of lagged measures. The results of the lagged measure of executive turnover, political ties, and shareholding variables are similar and in line with our main results shown in Table 3. Secondly, a two-stage least squares (2SLS) regression (an instrumental variable technique) is used to deal with the endogeneity problem whereby a year lagged measure of executive turnover, political ties, and shareholding has been used. Models 6, 7, 8, 9, and 10 of Table 6 show the results of 2SLS regression. The statistical outcomes confirm the validity. No weak instrumental variables were found whatsoever. The OLS results of Table 5 representing "endogeneity control" suggest that the significances of the coefficients are similar to the results of the 2SLS regression shown in Table 6.

Table 6. Endogeneity tests. Two-stage least square (2SLS) results for the political ties on executive turnover-CSR disclosure.

\begin{tabular}{|c|c|c|c|c|c|c|c|c|c|c|}
\hline \multirow{2}{*}{$\begin{array}{c}\text { Models } \\
\text { CSRD }\end{array}$} & \multicolumn{5}{|c|}{ Lagged OLS } & \multicolumn{5}{|c|}{ 2SLS } \\
\hline & Model 1 & Model 2 & Model 3 & Model 4 & Model 5 & Model 6 & Model 7 & Model 8 & Model 9 & Model 10 \\
\hline ET & $\begin{array}{c}-1.412^{* * *} \\
(-16.57)\end{array}$ & & $\begin{array}{c}-0.854^{* * *} \\
(-9.38)\end{array}$ & $\begin{array}{c}-1.980^{* * *} \\
(-20.46)\end{array}$ & & $\begin{array}{c}-0.996^{* *} \\
(-1.68)\end{array}$ & & $\begin{array}{c}-0.478^{* *} \\
(-1.46)\end{array}$ & $\begin{array}{c}-0.998^{* * * *} \\
(-1.69)\end{array}$ & \\
\hline PT & & $\begin{array}{c}-0.591 \text { *** } \\
(-3.91)\end{array}$ & $\begin{array}{c}-0.617^{* * *} \\
(-4.39)\end{array}$ & & $\begin{array}{c}-1.130 * * * \\
(-5.92)\end{array}$ & & $\begin{array}{c}-8.931 * * * * \\
(-3.31)\end{array}$ & $\begin{array}{l}-8.149^{*} \\
(-2.12)\end{array}$ & & $\begin{array}{c}-7.710^{* *} \\
(-2.45)\end{array}$ \\
\hline $\mathrm{SH}$ & & & $\begin{array}{c}0.283^{* * *} \\
(14.47)\end{array}$ & $\begin{array}{c}0.263^{* * *} \\
(14.49)\end{array}$ & $\begin{array}{c}0.283 * * * \\
(14.78)\end{array}$ & & & $\begin{array}{c}0.249 * * * \\
(2.18)\end{array}$ & $\begin{array}{c}0.278^{* * *} \\
(2.38)\end{array}$ & $\begin{array}{c}0.274^{* * *} \\
(2.15)\end{array}$ \\
\hline Interaction & & & & $\begin{array}{c}-0.056^{\text {*** }} \\
(-11.59)\end{array}$ & $\begin{array}{c}-0.050 * * * \\
(-4.60)\end{array}$ & & & & $\begin{array}{c}-0.128 \text { ** } \\
(-2.41)\end{array}$ & $\begin{array}{c}-0.088^{* * *} \\
(5.51)\end{array}$ \\
\hline BS & $\begin{array}{l}-0.011 \\
(-0.34)\end{array}$ & $\begin{array}{l}-0.039 \\
(-1.13)\end{array}$ & $\begin{array}{l}-0.030 \\
(-0.94)\end{array}$ & $\begin{array}{l}-0.007 \\
(-0.22)\end{array}$ & $\begin{array}{l}-0.044 \\
(-1.27) \\
\end{array}$ & $\begin{array}{l}-0.018 \\
(-0.52)\end{array}$ & $\begin{array}{c}-0.144 \text { ** } \\
(-2.42)\end{array}$ & $\begin{array}{c}-0.150 * * \\
(-1.77)\end{array}$ & $\begin{array}{l}0.044 \\
(0.62)\end{array}$ & $\begin{array}{l}-0.135 \\
(-2.08) \\
\end{array}$ \\
\hline ID & $\begin{array}{l}0.044 \\
(0.49)\end{array}$ & $\begin{array}{l}0.072 \\
(0.75)\end{array}$ & $\begin{array}{l}0.060 \\
(0.68)\end{array}$ & $\begin{array}{l}0.035 \\
(0.39)\end{array}$ & $\begin{array}{l}0.079 \\
(0.83)\end{array}$ & $\begin{array}{l}0.049 \\
(0.53)\end{array}$ & $\begin{array}{c}0.247^{* *} \\
(1.68)\end{array}$ & $\begin{array}{l}0.244 \\
(1.63)\end{array}$ & $\begin{array}{l}0.072 \\
(0.56)\end{array}$ & $\begin{array}{l}0.231 \\
(1.46)\end{array}$ \\
\hline TQ & $\begin{array}{l}-0.022 \\
(-0.71) \\
\end{array}$ & $\begin{array}{l}0.006 \\
(0.20) \\
\end{array}$ & $\begin{array}{l}-0.031 \\
(-1.03) \\
\end{array}$ & $\begin{array}{l}-0.004 \\
(-0.14)\end{array}$ & $\begin{array}{l}0.004 \\
(0.12) \\
\end{array}$ & $\begin{array}{l}-0.015 \\
(-0.48)\end{array}$ & $\begin{array}{l}0.132 \text { ** } \\
(2.17)\end{array}$ & $\begin{array}{l}0.152 \\
(1.75) \\
\end{array}$ & $\begin{array}{l}-0.115 \\
(-1.47)\end{array}$ & $\begin{array}{c}0.133 * * \\
(2.03)\end{array}$ \\
\hline BTMA & $\begin{array}{l}-0.016 \\
(-0.32)\end{array}$ & $\begin{array}{l}-0.021 \\
(-0.41)\end{array}$ & $\begin{array}{l}-0.107^{*} \\
(-2.21)\end{array}$ & $\begin{array}{l}-0.010 \\
(-0.22)\end{array}$ & $\begin{array}{l}-0.021 \\
(-0.42) \\
\end{array}$ & $\begin{array}{l}-0.012 \\
(-0.26)\end{array}$ & $\begin{array}{l}-0.098 \\
(-1.25) \\
\end{array}$ & $\begin{array}{l}-0.069 \\
(-0.56)\end{array}$ & $\begin{array}{l}-0.111 \\
(-1.32)\end{array}$ & $\begin{array}{l}-0.104 \\
(-1.23) \\
\end{array}$ \\
\hline AG & $\begin{array}{c}-0.334^{* *} \\
(-2.54)\end{array}$ & $\begin{array}{c}-0.330^{* *} \\
(-2.41)\end{array}$ & $\begin{array}{c}-0.338^{* *} \\
(-2.66)\end{array}$ & $\begin{array}{l}-0.144 \\
(-1.11)\end{array}$ & $\begin{array}{l}-0.282 \\
(-2.06)\end{array}$ & $\begin{array}{l}0.331^{* *} \\
(2.51)\end{array}$ & $\begin{array}{l}-0.023 \\
(-0.11)\end{array}$ & $\begin{array}{l}-0.0946 \\
(-0.41)\end{array}$ & $\begin{array}{c}-0.503 \text { ** } \\
(-2.53)\end{array}$ & $\begin{array}{l}-0.049 \\
(-0.21)\end{array}$ \\
\hline ROA & $\begin{array}{l}1.031 \\
(0.98)\end{array}$ & $\begin{array}{l}0.998 \\
(0.91)\end{array}$ & $\begin{array}{l}0.429 \\
(0.42)\end{array}$ & $\begin{array}{l}-0.442 \\
(-0.43)\end{array}$ & $\begin{array}{l}0.774 \\
(0.71)\end{array}$ & $\begin{array}{l}0.982 \\
(0.93)\end{array}$ & $\begin{array}{l}2.451 \\
(1.52)\end{array}$ & $\begin{array}{l}2.596 \\
(1.58)\end{array}$ & $\begin{array}{l}3.200 \\
(1.80)\end{array}$ & $\begin{array}{c}3.513 * * \\
(1.73)\end{array}$ \\
\hline ROE & $\begin{array}{l}-0.483 * \\
(-2.04)\end{array}$ & $\begin{array}{l}-0.566^{*} \\
(-2.30)\end{array}$ & $\begin{array}{c}-0.447^{* *} \\
(-1.95) \\
\end{array}$ & $\begin{array}{c}0.442 * \\
(-1.90) \\
\end{array}$ & $\begin{array}{l}-0.557^{*} \\
(-2.27)\end{array}$ & $\begin{array}{c}-0.505^{* *} \\
(-2.11)\end{array}$ & $\begin{array}{l}-0.524 \\
(-1.50) \\
\end{array}$ & $\begin{array}{l}-0.604 \\
(-1.62) \\
\end{array}$ & $\begin{array}{c}-0.358^{* *} \\
(-0.98)\end{array}$ & $\begin{array}{l}-0.552 \\
(-1.46) \\
\end{array}$ \\
\hline BM & $\begin{array}{c}-0.034^{* * *} \\
(-3.87)\end{array}$ & $\begin{array}{c}-0.033^{* * *} \\
(-3.59)\end{array}$ & $\begin{array}{c}-0.040^{* * *} \\
(-4.67)\end{array}$ & $\begin{array}{c}-0.027 * * * \\
(-3.11)\end{array}$ & $\begin{array}{c}-0.031 * * * \\
(-3.37)\end{array}$ & $\begin{array}{c}-0.035^{* * *} \\
(-3.90) \\
\end{array}$ & $\begin{array}{l}-0.017 \\
(-1.25) \\
\end{array}$ & $\begin{array}{l}-0.020 \\
(-1.25) \\
\end{array}$ & $\begin{array}{c}-0.037^{* * *} \\
(-2.96) \\
\end{array}$ & $\begin{array}{c}0.023^{* * *} \\
(-1.42) \\
\end{array}$ \\
\hline FL & $\begin{array}{l}0.354 \\
(1.16)\end{array}$ & $\begin{array}{l}0.273 \\
(0.86)\end{array}$ & $\begin{array}{l}0.555^{*} \\
(1.87)\end{array}$ & $\begin{array}{l}0.356 \\
(1.19)\end{array}$ & $\begin{array}{l}0.252 \\
(0.79)\end{array}$ & $\begin{array}{l}0.325 \\
(1.06)\end{array}$ & $\begin{array}{l}0.304 \\
(0.68)\end{array}$ & $\begin{array}{l}0.251 \\
(0.48)\end{array}$ & $\begin{array}{c}0.563 \\
(1.18)\end{array}$ & $\begin{array}{l}0.195 \\
(0.39)\end{array}$ \\
\hline
\end{tabular}


Table 6. Cont

\begin{tabular}{ccccccccccc}
\hline Models & \multicolumn{9}{c}{ Lagged OLS } & \multicolumn{3}{c}{ 2SLS } \\
\hline CSRD & Model 1 & Model 2 & Model 3 & Model 4 & Model 5 & Model 6 & Model 7 & Model 8 & Model 9 & Model 10 \\
\hline \multirow{2}{*}{ NE } & $-0.087^{* * *}$ & -0.053 & -0.148 & $-0.079^{* *}$ & -0.051 & $-0.076^{* *}$ & -0.003 & 0.029 & $-0.182^{* *}$ & $0.004^{* *}$ \\
& $(-2.53$ & $(-1.50)$ & $(-4.43)$ & $(-2.35)$ & $(-1.45)$ & $(-2.02)$ & $(-0.07)$ & $(0.45)$ & $(-1.81)$ & $(0.08)$ \\
\hline \multirow{2}{*}{ Constant } & $\begin{array}{c}7.364^{* * *} \\
(19.07)\end{array}$ & $\begin{array}{c}6.624^{* * *} \\
(16.60)\end{array}$ & $\begin{array}{c}1.531^{* *} \\
(2.77)\end{array}$ & $\begin{array}{c}7.245^{* * *} \\
(19.15)\end{array}$ & $\begin{array}{c}6.641^{* * *} \\
(16.70)\end{array}$ & $\begin{array}{c}7.120^{* * *} \\
(13.76)\end{array}$ & $\begin{array}{c}6.509^{* * *} \\
(11.55)\end{array}$ & $\begin{array}{c}13.934^{* * *} \\
(6.50)\end{array}$ & $\begin{array}{c}9.678^{* * *} \\
(16.63)\end{array}$ & $\begin{array}{c}6.560^{* * *} \\
(10.78)\end{array}$ \\
\hline YI & Included & Included & Included & Included & Included & Included & Included & Included & Included & Included \\
\hline R2 & 0.1023 & 0.0285 & 0.1639 & 0.1393 & 0.0351 & 0.0955 & 0.0351 & 0.1549 & 0.1549 & 0.04422 \\
\hline
\end{tabular}

Notes: ${ }^{*}, * * * *$, significant at $10 \%, 5 \%$, and $1 \%$, respectively. T-statistics are reported in parentheses. For a detailed description of variable, see Table 1 .

\section{Discussion and Conclusions}

The quality of CSR disclosure is reported to be under-fulfilled owing to various reasons whereby. Executive turnover is one of the prominent reasons reported in earlier studies. It has been studied in terms of its causal relationships with different antecedents and effects for voluntary and involuntary turnover including but not limited to large outside shareholders, the effect of poor performance, ownership of government, and incumbent's power. Few studies, nevertheless have examined the plausible negative influence of Political ties and executive turnover on the attributes of CSR in tandem to the shareholding status of the departing executive. The discontinuity of the power of the executive fosters serious concerns for the effectiveness and efficiency of CSR disclosure and therefore, empirical insight into this relation has been conducted in this study.

The quality of CSR disclosure is being investigated here for the dual influence of and executive turnover in Chinese listed firms. The research contributes to the discourse of quality of CSR disclosure uniquely in a sense that it links political ties of a firm and executive turnover simultaneously with the quality of CSR disclosure while unveiling the interplay of these phenomena under the effects of the shareholding status of the departing executive. This strengthens the premise of stakeholder theory in tandem with agency and upper echelon theories. From these perspectives, the analyses here offer a valuable contribution to the stakeholder theory of CSR in terms of the understanding of the underpinnings of the behavior of departing executive in political ties firms relevant to his/her shareholding status. This is because of the arousal of an already settled (in the shape of the incumbent executive) agency problems amongst different stakeholders due to executive turnover in political ties, harming the quality of CSR disclosure when he/she owns a larger shareholding.

We also investigated the extent to which political ties (whether an executive has experience as a government official) have any relation with the quality of CSR disclosure. This construct is a proxy for government control and pressure as discussed earlier in the light of political legitimacy theory and control-oriented perspective. Although it has been reported in the earlier studies that the likelihood of issuing CSR disclosure is more for the politically ties firms as compared to none connected ones, the quality of CSR disclosure has been overlooked at par.

The results of this study complement political legitimacy theory while incorporating the effect of relief from regulator control, which ultimately leads to the exacerbation of the quality of CSR disclosure. The potency of different kinds of political forces to handicap a firm, while addicting it with over-reliance on governmental support, is a notable thing and has strong repercussions in terms of the quality of CSR disclosure. Political ties is extensively reported as an effective trait for the promulgation of the quality of CSR disclosure and practices on part of a firm. Nonetheless, our results depict that in the context of China, political ties, and executive turnover are negatively related to the quality of CSR disclosure. It indicates that while considering political legitimacy theory, agency theory explains the trade-off of quality performance with financial performance, on behalf of opportunity costs, rejecting the "One size fits all" government-induced CSR policies. At an 
aggregate level, the findings foster that in a setting with (indirect influence of regulator); additional measures for effectiveness and efficiency are needed to be taken to ensure a holistic appraisal of government-induced policies, including but not limited to CSR practices and its quality.

The findings have valuable outcomes for policy-makers, research-practitioners, investors, and other stakeholders. First of all, the role of executive in politically ties Chinese firms for the implementation of different normative and progressive initiatives is more pronounced in China as compared to developed economies, and therefore to ensure the quality of CSR disclosure, their retention and shareholding status need due consideration. Different policies are needed for firms with different combinations of the above attributes. It can be concluded that the indirect influence of regulators through the political ties of executive affects the quality of CSR disclosure due to their turnover and appreciated ownership. Therefore, we culminate that political links and ownership of departing executive are active participants in the exacerbation of quality of CSR disclosure in political ties firms of China and resembling economies.

\section{Limitations and Future Research}

Like other research studies, our research has certain limitations. The context of China fosters different limitations in terms of institutional settings and firms' characteristics, and so therefore the results are not generalizable to other economies unless justified with resembling contextual traits. In addition, the political connection of the firms is operationalized through the history of jobs of the departing executive in governmental institutions; however, there are certain other alternative proxies to measure this phenomenon with more accuracy.

Future research can focus on the interplay of executive turnover, political ties, and CSR disclosure under the shareholding status of departing executive and test the compliance of legitimacy and agency theory in other institutional settings. In addition, the alternative proxies for political ties can be harnessed for their impact on the voluntary and involuntary turnover of executive.

Author Contributions: Conceptualization, F.R. and C.L.V.; methodology, F.R.; software, F.R.; validation, K.N., C.L.V. and C.F.; formal analysis, F.R.; investigation, C.L.V.; resources, F.R.; data curation, F.R.; writing—original draft preparation, C.L.V.; writing—review and editing, F.R.; visualization, C.F.; supervision, C.L.V.; project administration, C.L.V.; funding acquisition, C.L.V. All authors have read and agreed to the published version of the manuscript.

Funding: This research received no external funding.

Institutional Review Board Statement: Not applicable.

Informed Consent Statement: Not applicable.

Data Availability Statement: Data sharing not applicable.

Conflicts of Interest: The authors declare no conflict of interest.

\section{References}

1. Shleifer, A.; Vishny, R.W. Politicians and Firms. Q. J. Econ. 1994, 109, 995-1025. [CrossRef]

2. Cheng, Z.; Wang, F.; Keung, C.; Bai, Y. Will Corporate Political Connection Influence the Environmental Information Disclosure Level? Based on the Panel Data of A-Shares from Listed Companies in Shanghai Stock Market. J. Bus. Ethics 2017, 143, $209-221$. [CrossRef]

3. Kroszner, R.S.; Stratmann, T. Interest-group competition and the organization of congress: Theory and evidence from financial services' political action committees. Am. Econ. Rev. 1998, 88, 1163-1187.

4. Agrawal, A.; Knoeber, C.R. Do some outside directors play a political role? J. Law Econ. 2001, 44, 179-198. [CrossRef]

5. Fisman, R. Estimating the Value of Political Connections. Am. Econ. Rev. 2001, 91, 1095-1102. [CrossRef]

6. Johnson, S.; Mitton, T. Cronyism and capital controls: Evidence from Malaysia. J. Financ. Econ. 2003, 67, 351-382. [CrossRef]

7. Goldman, E.; Rocholl, J.; So, J. Do politically connected boards affect firm value? Rev. Financ. Stud. 2009, 22, 2331-2360. [CrossRef]

8. Cooper, M.J.; Gulen, H.; Ovtchinnikov, A.V. Corporate political contributions and stock returns. J. Financ. 2010, 65, 687-724. [CrossRef] 
9. Frankl, M.; Roberts, S. Female Executives in Healthcare Management in the context of the Upper Echelon Theory. J. Bus. Divers. 2018, 18, 98-112.

10. Pujari, D.; Peattie, K.; Wright, G. Organizational antecedents of environmental responsiveness in industrial new product development. Ind. Mark. Manag. 2004, 33, 381-391. [CrossRef]

11. Sharma, S. Managerial interpretations and organizational context as predictors of corporate choice of environmental strategy. Acad. Manag. J. 2000, 43, 681-697.

12. Bradly, A.; Nathan, G. Institutional CSR: Provision of public goods in developing economies. Soc. Responsib. J. 2019, 15, 874-887. [CrossRef]

13. Al-Htaybat, K.; von Alberti-Alhtaybat, L. Big Data and corporate reporting: Impacts and paradoxes. Account. Audit. Account. J. 2017, 30, 850-873. [CrossRef]

14. Cheng, L.T.; Leung, T. Government protection, political connection and management turnover in China. Int. Rev. Econ. Financ. 2016, 45, 160-176. [CrossRef]

15. Shen, W.; Cho, T.S. Exploring Involuntary Executive Turnover Through A Managerial Discretion Framework. Acad. Manag. Rev. 2005, 30, 843-854. [CrossRef]

16. Chang, E.C.; Wong, S.M. Governance with multiple objectives: Evidence from top executive turnover in China. J. Corp. Financ. 2009, 15, 230-244. [CrossRef]

17. Chaney, P.K.; Faccio, M.; Parsley, D. The quality of accounting information in politically connected firms. J. Account. Econ. 2011, 51, 58-76. [CrossRef]

18. Chaudhary, R. CSR and turnover intentions: Examining the underlying psychological mechanisms. Soc. Responsib. J. 2017, 13, 643-660. [CrossRef]

19. Bernard, Y.; Godard, L.; Zouaoui, M. The Effect of CEOs' Turnover on the Corporate Sustainability Performance of French Firms. J. Bus. Ethics 2018, 150, 1049-1069. [CrossRef]

20. Gray, R.; Kouhy, R.; Lavers, S. Corporate social and environmental reporting. Account. Audit. Account. J. 1995, 8, 47-77. [CrossRef]

21. Simpson, W.G.; Kohers, T. The Link Between Corporate Social and Financial Performance: Evidence from the Banking Industry. J. Bus. Ethics 2002, 35, 97-109. [CrossRef]

22. Godfrey, P.C.; Merrill, C.B.; Hansen, J.M. The relationship between corporate social responsibility and shareholder value: An empirical test of the risk management hypothesis. Strat. Manag. J. 2009, 30, 425-445. [CrossRef]

23. Cormier, D.; LeDoux, M.-J.; Magnan, M. The Informational Contribution of Social and Environmental Disclosures for Investors. Ssrn Electron. J. 2009, 49, 1276-1304. [CrossRef]

24. El Ghoul, S.; Guedhami, O.; Kwok, C.C.; Mishra, D.R. Does corporate social responsibility affect the cost of capital? J. Bank. Financ. 2011, 35, 2388-2406. [CrossRef]

25. Salama, A.; Anderson, K.; Toms, J. Does community and environmental responsibility affect firm risk? Evidence from UK panel data 1994-2006. Bus. Ethics A Eur. Rev. 2011, 20, 192-204. [CrossRef]

26. Lourenço, I.C.; Branco, M.C.; Curto, J.D.; Eugénio, T. How Does the Market Value Corporate Sustainability Performance? J. Bus. Ethics 2011, 108, 417-428. [CrossRef]

27. Cai, W.; Lee, E.; Wu, Z.; Xu, A.L.; Zeng, C. Do Economic Incentives of Controlling Shareholders Influence Corporate Social Responsibility Disclosure? A Natural Experiment. Int. J. Account. 2017, 52, 238-250. [CrossRef]

28. Michelon, G.; Rodrigue, M.; Trevisan, E. The marketization of a social movement: Activists, shareholders and CSR disclosure. Account. Organ. Soc. 2020, 80, 101074. [CrossRef]

29. Jamali, D.; Safieddine, A.M.; Rabbath, M. Corporate Governance and Corporate Social Responsibility Synergies and Interrelationships. Corp. Gov. Int. Rev. 2008, 16, 443-459. [CrossRef]

30. Hong, B.; Li, Z.; Minor, D. Corporate governance and executive compensation for corporate social responsibility. J. Bus. Ethics 2016, 136, 199-213. [CrossRef]

31. Ali, W.; Frynas, J.G.; Mahmood, Z. Determinants of Corporate Social Responsibility (CSR) Disclosure in Developed and Developing Countries: A Literature Review. Corp. Soc. Responsib. Environ. Manag. 2017, 24, 273-294. [CrossRef]

32. Freeman, R.E. The Politics of Stakeholder Theory: Some Future Directions. Bus. Ethics Q. 1994, 4, 409-421. [CrossRef]

33. Elijido-Ten, E.; Kloot, L.; Clarkson, P. Extending the application of stakeholder influence strategies to environmental disclosures: An exploratory study from a developing country. Account. Audit. Account. J. 2010, 23, 1032-1059. [CrossRef]

34. Brown, J.A.; Forster, W.R. CSR and Stakeholder Theory: A Tale of Adam Smith. J. Bus. Ethics 2012, 112, 301-312. [CrossRef]

35. Ellerup Nielsen, A.; Thomsen, C. Reporting CSR-what and how to say it? Corp. Commun. Int. J. 2007, 12, 25-40. [CrossRef]

36. Ramadhini, A.; Adhariani, D.; Djakman, C.D. The effects of external stakeholder pressure on CSR disclosure: Evidence from Indonesia. Dlsu Bus. Econ. Rev. 2020, 29, 29-39.

37. Snider, J.; Hill, R.P.; Martin, D. Corporate social responsibility in the 21st century: A view from the world's most successful firms. J. Bus. Ethics 2003, 48, 175-187. [CrossRef]

38. Bowen, D.E.; Siehl, C. The future of human resource management: March and Simon (1958) revisited. Hum. Resour. Manag. 1997, 36, 57-63. [CrossRef]

39. Williamson, O.E. Visible and invisible governance. Am. Econ. Rev. 1994, 84, 323-326.

40. Jackofsky, E.F.; Peters, L.H. Job turnover versus company turnover: Reassessment of the March and Simon participation hypothesis. J. Appl. Psychol. 1983, 68, 490. [CrossRef] 
41. Hulin, C.L.; Roznowski, M.; Hachiya, D. Alternative opportunities and withdrawal decisions: Empirical and theoretical discrepancies and an integration. Psychol. Bull. 1985, 97, 233. [CrossRef]

42. Helmich, D.L.; Brown, W.B. Successor Type and Organizational Change in the Corporate Enterprise. Adm. Sci. Q. 1972, 17, 371. [CrossRef]

43. Cao, Q.; Maruping, L.M.; Takeuchi, R. Disentangling the Effects of CEO Turnover and Succession on Organizational Capabilities: A Social Network Perspective. Organ. Sci. 2006, 17, 563-576. [CrossRef]

44. Reverte, C. The Impact of Better Corporate Social Responsibility Disclosure on the Cost of Equity Capital. Corp. Soc. Responsib. Environ. Manag. 2011, 19, 253-272. [CrossRef]

45. Zhu, H.; Lin, Y. Wealth effect of senior executive turnover in China. Econ. Sci. 2003, 4, 85-94.

46. Chen, G.; Hambrick, D.C. CEO Replacement in Turnaround Situations: Executive (Mis) Fit and Its Performance Implications. Organ. Sci. 2012, 23, 225-243. [CrossRef]

47. Fee, C.E.; Hadlock, C.J. Raids, Rewards, and Reputations in the Market for Managerial Talent. Rev. Financ. Stud. 2003, 16, 1315-1357. [CrossRef]

48. Grinyer, P.H.; Norburn, D. Planning for existing markets: Perceptions of executives and financial performance. J. R. Stat. Soc. Ser. A 1975, 138, 70-97. [CrossRef]

49. Reitenga, A.L.; Tearney, M.G. Mandatory CEO Retirements, Discretionary Accruals, and Corporate Governance Mechanisms. J. Account. Audit. Financ. 2003, 18, 255-280. [CrossRef]

50. Barefoot, L.A.; Hayday, C.F.; Vaughn, S.; Lenox, B. The Risks of Pre-Petition Executive Bonuses in Distressed Scenarios. Am. Bankruptcy Inst. J. 2021, 40, 44-76.

51. Marquis, C.; Qian, C. Corporate Social Responsibility Reporting in China: Symbol or Substance? Organ. Sci. 2014, 25, 127-148. [CrossRef]

52. Wang, Y.; Ma, J.; Wang, T. Do all female directors have the same impact on corporate social responsibility? The role of their political connection. Asia Pac. J. Manag. 2021, 87, 1-28. [CrossRef]

53. Chen, J.; Dickson, B.J. Allies of the State: China's Private Entrepreneurs and Democratic Change; Harvard University Press: Cambridge, MA, USA, 2010.

54. Wahab, E.A.A.; Jamaludin, M.F.; Agustia, D.; Harymawan, I. Director Networks, Political Connections, and Earnings Quality in Malaysia. Manag. Organ. Rev. 2020, 16, 687-724. [CrossRef]

55. Yang, X.; Rivers, C. Antecedents of CSR Practices in MNCs' Subsidiaries: A Stakeholder and Institutional Perspective. J. Bus. Ethics 2009, 86, 155-169. [CrossRef]

56. Nee, V.; Opper, S. Political Capital in a Market Economy. Soc. Forces 2010, 88, 2105-2132. [CrossRef]

57. Schaap, D. Police trust-building strategies. A socio-institutional, comparative approach. Polic. Soc. 2020, 5, 1-17. [CrossRef]

58. Wong, S.H.-W. Political Connections and Firm Performance: The Case of Hong Kong. J. East. Asian Stud. 2010, 10, 275-314. [CrossRef]

59. Fan, J.P.; Wong, T.J.; Zhang, T. Politically connected CEOs, corporate governance, and Post-IPO performance of China's newly partially privatized firms. J. Financ. Econ. 2007, 84, 330-357. [CrossRef]

60. Xu, B.; Zeng, T. Profitability, state ownership, tax reporting and corporate social responsibility: Evidence from Chinese listed firms. Soc. Responsib. J. 2016, 12, 23-31. [CrossRef]

61. Guthrie, D. China and Globalization: The Social, Economic, and Political Transformation of Chinese Society; Routledge: New York, NY, USA, 2012.

62. Abolhassani, M.; Wang, Z.; De Haan, J. How Does Government Control Affect Firm Value? New Evidence for China. Kyklos 2020, 73, 3-21. [CrossRef]

63. $\mathrm{Wu}, \mathrm{W} . ; \mathrm{Wu}, \mathrm{C}$; Rui, O.M. Ownership and the Value of Political Connections: Evidence from China. Eur. Financ. Manag. 2010, 18, 695-729. [CrossRef]

64. Wu, W.; Wu, C.; Zhou, C.; Wu, J. Political connections, tax benefits and firm performance: Evidence from China. J. Account. Public Policy 2012, 31, 277-300. [CrossRef]

65. Liu, X.; Anbumozhi, V. Determinant factors of corporate environmental information disclosure: An empirical study of Chinese listed companies. J. Clean. Prod. 2009, 17, 593-600. [CrossRef]

66. Jianying, L.; Weiqi, L.; Dongliang, Y.; Liu, W.; Yuan, D. Private Entrepreneurs of Communist Party Members and Corporate Social Responsibility: Evidence from Chinese Private Enterprise Survey. Theor. Econ. Lett. 2020, 10, 635-654. [CrossRef]

67. Lin, L.-W. Corporate social responsibility in China: Window dressing or structural change. Berkeley J. Int. Law 2010, $28,64$.

68. Gong, G.; Huang, X.; Wu, S.; Tian, H.; Li, W. Punishment by Securities Regulators, Corporate Social Responsibility and the Cost of Debt. J. Bus. Ethics 2020, 1-20. [CrossRef]

69. Ren, S.; Wei, W.; Sun, H.; Xu, Q.; Hu, Y.; Chen, X. Can mandatory environmental information disclosure achieve a win-win for a firm's environmental and economic performance? J. Clean. Prod. 2020, 250, 119530. [CrossRef]

70. Deegan, C. Introduction: The legitimising effect of social and environmental disclosures-a theoretical foundation. Account. Audit. Account. J. 2002, 15, 282-311. [CrossRef]

71. Islam, M.T.; Kokubu, K.; Nishitani, K. Corporate social reporting in the banking industry of Bangladesh: A test of legitimacy theory. Soc. Responsib. J. 2020, 17, 198-225. [CrossRef] 
72. Zhao, M. CSR-Based Political Legitimacy Strategy: Managing the State by Doing Good in China and Russia. J. Bus. Ethics 2012, 111, 439-460. [CrossRef]

73. Rauf, F.; Voinea, C.L.; Bin Azam Hashmi, H.; Fratostiteanu, C. Moderating Effect of Political Embeddedness on the Relationship between Resources Base and Quality of CSR Disclosure in China. Sustainability 2020, 12, 3323. [CrossRef]

74. Ling, L.; Zhou, X.; Liang, Q.; Song, P.; Zeng, H. Political connections, overinvestments and firm performance: Evidence from Chinese listed real estate firms. Financ. Res. Lett. 2016, 18, 328-333. [CrossRef]

75. Krammer, S.M.; Jiménez, A. Do political connections matter for firm innovation? Evidence from emerging markets in Central Asia and Eastern Europe. Technol. Soc. Chang. 2020, 151, 119669. [CrossRef]

76. Johnson, B.R.; Connolly, E.J.; Carter, T.S. Corporate social responsibility: The role of Fortune 100 companies in domestic and international natural disasters. Corp. Soc. Responsib. Environ. Manag. 2010, 18, 352-369. [CrossRef]

77. Gillan, S.L. Recent Developments in Corporate Governance: An Overview. J. Corp. Financ. 2006, 12, 381-402. [CrossRef]

78. Martínez-Ferrero, J.; Rodríguez-Ariza, L.; García-Sánchez, I.-M. Corporate social responsibility as an entrenchment strategy, with a focus on the implications of family ownership. J. Clean. Prod. 2016, 135, 760-770. [CrossRef]

79. Zhuang, J. Some conceptual issues of corporate governance. Asian Dev. Bank Manila 1999, 13. Available online: https:/ / catalogue. nla.gov.au/Record/385034 (accessed on 3 March 2021).

80. Cao, F.; Peng, S.; Ye, K. Multiple large shareholders and corporate social responsibility reporting. Emerg. Mark. Rev. 2019, 38, 287-309. [CrossRef]

81. Xu, S.; Chen, X.; Li, A.; Xia, X. Disclosure for whom? Government involvement, CSR disclosure and firm value. Emerg. Mark. Rev. 2020, 44, 100717. [CrossRef]

82. Bozec, Y.; Laurin, C. Large Shareholder Entrenchment and Performance: Empirical Evidence from Canada. J. Bus. Financ. Account. 2008, 35, 25-49. [CrossRef]

83. Rinaldo, D.; Puspita, V.A. Independent Parties in Minimizing Agency Problem in Indonesia: An Alternative Model. Holist. J. Bus. Public Adm. 2020, 11, 13-28. [CrossRef]

84. Shu, P.-G.; Chiang, S.-J. The impact of corporate governance on corporate social performance: Cases from listed firms in Taiwan. Pac. Basin Financ. J. 2020, 61, 101332. [CrossRef]

85. Clarkson, P.M.; Li, Y.; Richardson, G.D.; Vasvari, F.P. Revisiting the relation between environmental performance and environmental disclosure: An empirical analysis. Account. Organ. Soc. 2008, 33, 303-327. [CrossRef]

86. Gray, R.; Javad, M.; Power, D.M.; Sinclair, C.D. Social and Environmental Disclosure and Corporate Characteristics: A Research Note and Extension. J. Bus. Financ. Account. 2001, 28, 327-356. [CrossRef]

87. Fallan, E.; Fallan, L. Voluntarism versus regulation. J. Account. Organ. Chang. 2009, 5, 472-489. [CrossRef]

88. Darnall, N.; Henriques, I.; Sadorsky, P. Adopting Proactive Environmental Strategy: The Influence of Stakeholders and Firm Size. J. Manag. Stud. 2009, 47, 1072-1094. [CrossRef]

89. Wiseman, J. An evaluation of environmental disclosures made in corporate annual reports. Account. Organ. Soc. 1982, 7, 53-63. [CrossRef]

90. Zeng, S.; Xu, X.; Dong, Z.; Tam, V.W. Towards corporate environmental information disclosure: An empirical study in China. J. Clean. Prod. 2010, 18, 1142-1148. [CrossRef]

91. Chen, C.J.P.; Li, Z.; Su, X.; Sun, Z. Rent-seeking incentives, corporate political connections, and the control structure of private firms: Chinese evidence. J. Corp. Financ. 2011, 17, 229-243. [CrossRef]

92. Wang, Z.; Reimsbach, D.; Braam, G. Political embeddedness and the diffusion of corporate social responsibility practices in China: A trade-off between financial and CSR performance? J. Clean. Prod. 2018, 198, 1185-1197. [CrossRef]

93. Xiong, R.; Wei, P.; Yang, J.; Cristofini, L.A. Impact of top executive turnover on firms' R\&D investment: Evidence from China. Innovation 2020, 1-25. [CrossRef]

94. Li, H.; Meng, L.; Wang, Q.; Zhou, L.-A. Political connections, financing and firm performance: Evidence from Chinese private firms. J. Dev. Econ. 2008, 87, 283-299. [CrossRef]

95. Zhou, P.; Arndt, F.; Jiang, K.; Dai, W. Looking Backward and Forward: Political Links and Environmental Corporate Social Responsibility in China. J. Bus. Ethics 2020, 1-19. [CrossRef]

96. Jiang, F.; Cai, W.; Wang, X.; Zhu, B. Multiple large shareholders and corporate investment: Evidence from China. J. Corp. Financ. 2018, 50, 66-83. [CrossRef]

97. Zhu, J.; Jiang, D.; Shen, Y.; Shen, Y. Does regional air quality affect executive turnover at listed companies in China? Econ. Model. 2021, 97, 428-436. [CrossRef]

98. Attig, N.; El Ghoul, S.; Guedhami, O. Do multiple large shareholders play a corporate governance role? Evidence from East Asia. J. Financ. Res. 2009, 32, 395-422. [CrossRef]

99. Cherian, J.; Sial, M.S.; Tran, D.K.; Hwang, J.; Khanh, T.H.T.; Ahmed, M. The Strength of CEOs'Influence on CSR in Chinese listed Companies. New Insights from an Agency Theory Perspective. Sustain. J. Rec. 2020, 12, 2190. [CrossRef]

100. Naveed, K.; Voinea, C.; Ali, Z.; Rauf, F.; Fratostiteanu, C. Board Gender Diversity and Corporate Social Performance in Different Industry Groups: Evidence from China. Sustainability 2021, 13, 3142. [CrossRef]

101. Dai, J.; Lu, C.; Qi, J. Corporate Social Responsibility Disclosure and Stock Price Crash Risk: Evidence from China. Sustain. J. Rec. 2019, 11, 448. [CrossRef] 
102. Meng, X.H.; Zeng, S.X.; Tam, C.M.; Xu, X.D. Whether Top Executives' Turnover Influences Environmental Responsibility: From the Perspective of Environmental Information Disclosure. J. Bus. Ethics 2013, 114, 341-353. [CrossRef]

103. Qian, W.; Chen, X. Corporate environmental disclosure and political connection in regulatory and leadership changes: The case of China. Br. Account. Rev. 2021, 53, 100935. [CrossRef]

104. Chi, W.; Wang, Y. Ownership, performance and executive turnover in China. J. Asian Econ. 2009, 20, 465-478. [CrossRef]

105. Guo, M.; Hu, Y.; Zhang, Y.; Tian, F. State-Owned Shareholding and CSR: Do Multiple Financing Methods Matter?-Evidence from China. Sustain. J. Rec. 2019, 11, 1292. [CrossRef]

106. Harjoto, M.A.; Jo, H. Corporate Governance and CSR Nexus. J. Bus. Ethics 2011, 100, 45-67. [CrossRef]

107. Muttakin, M.B.; Mihret, D.G.; Khan, A. Corporate political connection and corporate social responsibility disclosures. Account. Audit. Account. J. 2018, 31, 725-744. [CrossRef] 